\title{
IMPLEMENENTASI PROGRAM BIMBINGAN DAN KONSELING DALAM KURIKULUM 2013 DAN PROFESIONALISASI BIMBINGAN DAN KONSELING DI MADRASAH
}

\author{
Muh. Afroji \\ Widyaiswara Ahli Madya Pusdiklat Tenaga Teknis Pendidikan dan \\ Keagamaan \\ Email: muhafroji@yahoo.co.id
}

\begin{abstract}
ABSTRAK
Karya tulis ini bertujuan untuk mengetahui implementasi program program bimbingan dan konseling dalam kurikulum 2013 dan profesionalisasi Bimbingan dan konseling (BK) di madrasah. Bagaimana gap antara teori-teori yang terdapat dalam buku-buku maupun regulasi yang terkait dengan bimbingan dan konseling dan realita pelaksanaannya di madrasah. Metode penulisan ini adalah library research yaitu dengan mengkaji buku-buku dan regulsasi yang terkait dengan bahasan. Tulisan ini diharapkan akan bermanfaat bagi Guru BK/Konselor untuk menambah wawasannya, bagi kepala madrasah untuk dapat dijadikan pengambilan kebijakan dalam menyusun program kegiatannya, dan bagi Kementerian Agama untuk dapat dilakukan kebijakan penyetaraan Guru BK yang tidak memiliki ijazah BK. Kurikulum 2013 terbit karena mengingat adanya tantangan yang dihadapi, baik tantangan internal maupuan tantangan eksternal. Selain itu, dalam menghadapi tuntutan perkembangan zaman dirasa perlu adanya penyempurnaan pola pikir dan penguatan tata kelola kurikulum serta pendalam dan perluasan materi. Tema kurikulum 2013 yaitu mengasilkan insan Indonesia yang produktif, kreatif, inovatif, dan afektif melaui penguatan sikap, keterampilan, dan pengetahuan yang terintegrasi. Program bimbingan dan konseling yang seharusnya dibuat oleh Guru BK/Konselor madrasah apakah telah mengikuti sesuai dengan pedoman yang telah diterbitkan oleh pemerintah yang meliputi konsep dasar BK, prinsip-prinsip BK, bidang layanan BK, dan jenis-jenis layanan dapat dilihat dari uraian implementasi program BK. Demikian juga mengenai profesionalisi BK di madrasah, idealnya profesi seorang Guru BK/ Konselor memiliki kualifikasi profesi sesuai dengan peraturan pemerintah, dimana sekurang-kurangnya berpendidikan S-1 dari program bimbingan dan konseling. Implementasi program BK dalam Kurikulum 2013 dan
\end{abstract}


profesionalisasi guru BK dapat dilaksanakan sesuai dengan kemampuan yang dimiliki guru BK, walaupun berbagai keterbatasan yang ada.

Kata kunci: kurikulum 2013, program BK, profesionalisasi BK.

\begin{abstract}
This paper aims to elaborate on the long-term education program for the implementation of guidance and counseling in the 2013 curriculum and professionalization Guidance and Counseling (GC) in madrasas, gap theories available in books or regulations related to guidance and counseling and the reality of their implementation in madrasas. This research method is library research that is by reviewing books and regulations related to the discussion. This writing is expected to be useful for counselors / counselors to add insight, to madrasah heads to be used in the preparation of their activity programs, and for ministries to be carried out policy of equalizing BK Teachers who do not have a BK diploma. The 2013 curriculum was issued because considering there were challenges, both internal challenges and external challenges. In addition, in colliding with time that is felt necessary to improve the pattern of the pokir and strengthen the governance of curriculum and depth and material. The 2013 curriculum theme is to produce productive, creative, innovative, affective Indonesian people through integrated attitudes, skills and knowledge. Guidance and counseling programs made by madrasah GC / Counselor teachers are in accordance with the guidelines issued by the government which cover the concept of GC, GC principles, GC services, and various types of programs. GC. Likewise regarding the professionalism of $B K$ in madrasas, ideally the profession of a counselor / counselor has professional qualifications in accordance with government regulations, where at least S-1 education from guidance and counseling programs. The implementation of the GC program in 2013 Kjrikulum and the professionalization of the BK teacher can be carried out in accordance with their abilities, despite various limitations.
\end{abstract}

Keywords: 2013 curriculum, GC program, GC professionalization.

A. PENDAHULUAN

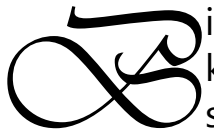

imbingan konseling diposisikan secara legal formal sebagai profesi dalam dunia pendidikan telah tercantum dalam
Undang-Undang Negara Republik Indonesia Nomor 20 Tahun 2003 tentang Sistem Pendidikan Nasional bahwa Pendidik adalah tenaga kependidikan yang berkualifikasi sebagai guru, 
dosen, konselor, pamong belajar, widyaiswara, tutor, instruktur, fasilitator, dan sebutan lain yang sesuai dengan kekhususannya, serta berpartisipasi dalam menyelenggarakan pendidikan.

Terkait dengan implementasi kurikulum 2013, garapan guru bimbingan dan konseling adalah peminatan siswa. Madrasah sebagai salah satu lembaga pendidikan masyarakat Indonesia merupakan penunjang pembangunan nasional di bidang pendidikan yang berlandaskan agama dan dapat dijadikan wadah untuk mengatasi pergeseran dan perubahan nilai-nilai negatif yang mungkin muncul pada masa kini. Program Bimbingan dan Konseling Madrasah (Madrasah Ibtidaiyah, Tsanawiyah dan Aliyah) terus mendapat perhatian, dengan harapan lulusan Madrasah memiliki kompetensi sesuai dengan harapan masyarakat, yaitu mampu menjadi manusia yang ber takwa, mandiri, memiliki pengetahuan dan keterampilan, memahami diri sendiri dan menyadari martabatnya.

SK Madrasah Nomor 0489/U/ 1993 pasal 1 butir 6, yang menyatakan bahwa madrasah adalah sekolah umum yang berciri khas agama Islam yang diselenggarakan oleh Departemen Agama. Oleh karena itu, adanya persamaan dalam pelaksanaan pendidikan pada madrasah dengan sekolah-sekolah umum. Persamaan itu mengandung harapan bahwa komponen-komponen yang diperlukan dalam proses pendidikan yaitu administrasi dan supervisi, pengajaran dan pembinaan siswa dapat berjalan sebagai suatu sistem yang saling menunjang.

Bimbingan dan konseling sebagai komponen pelayaan dan pembinaan siswa, pada pelaksana di madrasah belum berjalan secara baik. Keadaan ini memerlukan usaha-usaha penyempurnaan seperti pengadaan tenaga bimbingan yang profesional, penyediaan sarana dan prasarana yang memadai, serta program bimbingan yang baik.

Bertolak dari latar belakang masalah yang telah diuraikan di atas, dapat diidentifikasi masalah sebagai berikut:

1. Bagaimana bimbingan dan konseling di Madrasah?

2. Bagaimana seharusnya petugas bimbingan/konselor melaksanakan bimbingan di madrasah?

3. Bagaimana implemenentasi kurikulum 2013 dan profesionalisasi bimbingan dan konseling di madrasah?

4. Bagaimana implemenentasi program bimbingan dan konseling dalam kurikulum 2013 dan profesionalisasi bimbingan dan konseling dapat dilaksanakan di Madrasah? 
Di antara sejumlah masalah di atas, penulis hanya akan membahas "Bagaimana implemenentasi program bimbingan dan konseling dalam kurikulum 2013 dan profesionalisasi bimbingan dan konseling dapat dilaksanakan di madrasah?"

Tujuan tulisan ini adalah untuk mengetahui sejauh mana implementasi program BK dalam Kurikulum 2013 dan profesionalisasi BK di Madrasah.

Penulisan karya ilmiah ini diharapkan dapat bermanfaat, antara lain:

1. Bagi guru bimbingan dan konseling sebagai bahan masukan dalam upaya memberikan layanan bimbingan dan konseling di madrasah;

2. Bagi widyaiswara, dapat dijadikan bahan diklat materi bimbingan dan konseling; dan

3. Bagi lembaga diklat dapat dijadikan bahan pengambilan kebijakan dalam melaksanakan diklat guru bimbingan dan konseling.

\section{B. METODE PENELITIAN}

Metode penulisan ini adalah library research (studi kepustakaan) atau penelitian literature, yaitu

penelitian dengan mengkaji buku-buku dan regulsasi yang terkait dengan bahasan. Studi kepustakaan adalah kegiatan untuk menghimpun informasi yang relevan dengan topik atau masalah yang menjadi obyek penelitian. Informasi tersebut dapat diperoleh dari buku-buku, karya ilmiah, tesis, disertasi, ensiklopedia, internet, dan sumber-sumber lain.

Penelitian Literatur juga sering disebut dengan istilah penelitian kepustakaan (library research). Menurut Noeng Muhadjir, penelitian kepustakaan itu lebih memerlukan olahan filosofis dan teoritis daripada uji empiris di lapangan (Noeng Muhadjir, 1996:169). Karena sifatnya teoritis dan filosofis, penelitian kepustakaan ini sering menggunakan pendekatan filosofis (philosophical approach) daripada pendekatan yang lain. Metode penelitiannya mencakup sumber data, pengumpulan data, dan analisis data (http:// whiteacademic.blogspot. com/2015/03/pengertian-danjenis-jenis-penelitian.html)

Peneliti berusaha untuk
memperoleh sumber data
dengan membaca buku-buku
ilmiah, peraturan atau peundang-
undangan, dan buku-buku
pedoman yang terkait dengan
permasalahan.


C. PEMBAHASAN

\section{Kurikulum 2013 dan Bimbingan Konseling}

a. Kurikulum 2013

Pengembangan kurikulum 2013 telah dilakukan Kementerian Pendidikan dan Kebudayaan mengingat adanya tantangan yang dihadapi, baik tantangan internal maupuan tantangan eksternal. Selain itu, dalam menghadapi tuntutan perkembangan zaman dirasa perlu adanya penyempurnaan pola pokir dan penguatan tata kelola kurikulum serta pendalaman dan perluasan materi. Tema kurikulum 2013 yaitu menghasilkan insan Indonesia yang produktif, kreatif, inovatif, dan afektif melaui penguatan sikap, keterampilan, dan pengetahuan yang terintegrasi.

Kurikulum 2013 merupakan kurikulum yang berbasis kompetensi, oleh karena itu pengembangan kurikulum diarahkan pada pencapaian kompetensi yang dirumuskan dalam Standar Kompetensi Lulusan. Struktur kurikulum terdiri atas sejumlah mata pelajaran, beban belajar, dan kalender pendidikan. Mata pelajaran terdiri atas: (1) mata pelajaran wajib diikuti oleh seluruh peserta didik pada satu satuan pendidikan pada setiap satuan pendidikan, (2) mata pelajaran pilihan yang diikuti oleh peserta didik sesuai dengan pilihan mereka masing-masing.
Bimbingan dan konseling tidak termasuk ke dalam strukutur kurikulum 2013. Hal ini dikarenakan bimbingan dan konseling bukanlah mata pelajaran yang diberikan melalui proses pembelajaran, akan tetapi lebih pada proses pemberian layanan. Pelayanan bimbingan dan konseling lebih pada tindakan pemberian bantuan kepada peserta didik agar mampu mengembangkan potensi, bakat, dan minat mereka secara optimal, seperti membantu mereka dalam pengembangan kehidupan pribadi, sosial, pembelajaran, serta perencanaan dan pengembangan karier. Pelayanan bimbingan dan konseling dilakukan secara individual, kelompok, atau klasikal sesuai dengan kebutuhannya. Bimbingan dan konseling juga membantu peserta didik untuk mengatasi kelemahan atau hambatan serta masalah yang dihadapinya.

b. Bimbingan dan Konseling

\section{Bimbingan}

merupakan terjemahan dari bahasa Inggris "guidance" yang berasal dan kata kerja "to guide", yang mempunyai arti menunjukkan, memberikan jalan, atau menuntun orang lain ke arah tujuan yang bermanfaat. Bimbingan yang tercantum dalam surat al-fätihah ayat 6 :

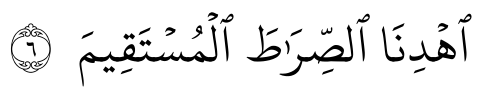

"Bimbinglah kami ke jalan yang lurus". (Q. S. 1: 6). 
Berbagai batasan tentang bimbingan telah dikemukakan oleh para ahli bimbngan dan konseling, yang pada umumnya terdapat kesesuaian dalam memberikan batasan-batasan itu.

Prayitno \& Erman Amti (2015: 99) mengemukakan: "Bimbingan adalah proses pemberian bantuan yang dilakukan oleh orang yang ahli kepada seorang atau beberapa orang individu, baik anak-anak, remaja, maupun dewasa; agar orang yang dibimbing dapat mengembangkan kemampuan dirinya sendiri dan mandiri; dengan memanfaatkan kekuatan individu dan sarana yang ada dan dapat dikembangkan; berdasarkan norma-norma yang berlaku."

Bimbingan merupakan suatu proses bantuan yang diberikan kepada individu (siswa) agar dapat memperkembangkan potensi-potensi yang dimiliki, mengenali dirinya sendiri, mengatasi persoalan-persoalan sehingga mereka dapat menentukan sendiri jalan hidupnya secara bertanggungjawab tanpa bergantung kepada orang lain.

Konseling merupakan kata serapan dari bahasa Inggris "counseling" yang berarti penyuluhan. Upaya untuk membedakan pengertian bidang pertanian, penyuluhan hukum, penyuluhan agama maka istilah penyuluhan di sekolah diganti pada tahun 1980-an dengan istilah "konseling" disebabkan alasan profesional dan bukan sematamata soal bahasa atau istilah.

Dalam kamus bimbingan dan konseling dijelaskan tentang batasan konseling. Konseling adalah hubungan timbal balik di antara dua individu yang seorang karena keahliannya (konselor) dapat membantu klien (yang mempunyai problem). Melalui pertemuan atau hubungan timbal balik itu, konselor berupaya menolong klien untuk memahami dirinya dan probelemnya agar klien dapat mengatasi problem yang sedang dihadapinya.

Konseling merupakan bagian program bimbingan di sekolah/ madarsah, merupakan inti bimbingan yaitu sebagai salah satu jenis layanan bimbingan yang merupakan inti dan bimbingan. Apabila bimbingan bersifat preventif sedangkan konseling bersifat kuratif yaitu usaha untuk memberikan bantuan terhadap individu yang sedang menghadapi masalah yang kemudian konselor memberikan pandanganpandangan dengan menunjukkan beberapa alternatif yang akan diambil klien.

Konseling dapat diartikan sebagai suatu pertemuan langsung antara konselor yang berusaha menolong klien dalammenghadapi, menjelaskan, memecahkan dan mengulangi masalah penyesuaian diri. Agar proses konseling dapat 
berjalan dengan baik dan mencapai sasaran yang diinginkan diperlukan keahlian tertentu yang dimiliki oleh seorang konselor. Ahli memahami siswa, ahli dalam menemukan dan mencari kemungkinan yang tersedia bagi klien dan sebagainya tanpa melupakan bahwa klien hidup dalam masyarakat yang mempunyai norma-norma tertentu.

Bimbingan dan Konseling merupakan proses bantuan atau pertolongan yang diberikan oleh pembimbing (konselor) kepada individu(konseli)melaluipertemuan tatap muka atau hubungan timbal balik antara keduanya, agar konseli memiliki kemampuan atau kecakapan melihat dan menemukan masalahnya serta mampu memecahkan masalahnya sendiri. Atau proses pemberian bantuan atau pertolongan yang sistematis dari pembimbing (konselor) kepada konseli (siswa) melalui pertemuan tatap muka atau hbungan timbal balik antara keduanya untuk mengungkap masalah konseli sehingga konseli mampu melihat masalah sendiri, mampu menerima dirinya sendiri sesuai dengan potensinya, dan mampu memecahkan sendiri masalah yang dihadapinya. (Tohirin, 2009: 26)

Norma-norma yang berlaku bagi siswa Madrasah memiliki ciri khusus, misalnya apabila seorang siswa bertemu dengan guru sendirinya maka ia akan mengucapkan salam dan mencium tangan gurunya itu. Hal sernacam ini jarang terlihat pada siswa sekolah umum. Mengucapkan salam dan mencium tangan guru seperti contoh tersebut merupakan hal seperti itu, berarti ada sesuatu yang 'terjadi' pada dirinya. Peristiwa seperti itu merupakan kepedulian konselor untuk berusaha mengetahui mengapa siswa tersebut demikian. Oleh karena itu konselor di samping memiliki kualifikasi tertentu juga dituntut memiliki pengetahuan agama yang memadai, sehingga dapat dikatakan seorang konselor yang bertugas di madrasah hendaklah dapat memberikan layanan bimbingan yang religius Islami.

Pendekatan yang dilakukan konselor secara khusus, artinya di samping pendekatan-pendekatan yang ada pada teori-teorikonseling, konselor juga menggunakan pendekatan yang diwarnai oleh ajaran agama. Misalnya pendekatan yang terdapat dalam Alquran sebagaimana tertuang dalam surat annahl ayat 125 :

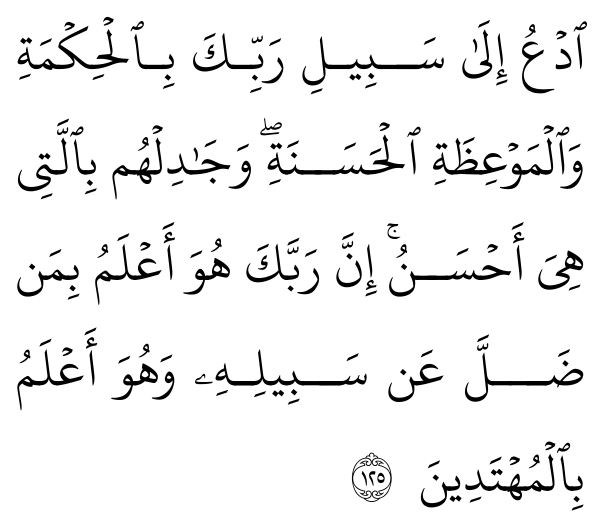


Serulah (manusia) kepada jalan Tuhan-mu dengan hikmah dan pelajaran yang baik dan bantahlah mereka dengan cara yang baik. (Q.S. 15:125)

Ayat tersebut menjelaskan tentang dakwah. Bagi konselor dapat mengambil pelajaran ayat dengan cara melaksanakan tugas hendaklah menggunakan perkataan yang mengandung hikmah, tegas dan benar, penuh bijaksana, berdiskusi yang sehat, sehingga klien memahami dan mengetahui keadaan dirinya dan dapat memutuskan sesuatu tindakan yang akan diambilnya.

Mengutip buku Petunjuk Pelaksanaan Bimbingan dan Konseling Kurikulum 2004 disebutkan bahwa pelayanan bimbingan dan konseling mendasarkan layanan dan kegiatannya pada sejumlah prinsip yaitu:

1. Prinsip-prinsip yang berkenaan dengan sasaran layanan.

a. Bimbingan dan konseling melayani semua individu tanpa memandang umur, jenis kelamin, suku, agama dan status sosial ekonomi.

b. Bimbingan dan konseling berurusan dengan pribadi dan tingkah laku individu yang unik dan dinamis.

c. Bimbingan dan konseling $\mathrm{m}$ e $\mathrm{m} \mathrm{perh}$ a t i ka $\mathrm{n}$ sepenuhnya

tahap dan berbagai aspek perkembangan individu.

d. Bimbingan dan konseling memberikan perhatian utama kepada perbedaan individual yang menjadi orientasi pokok pelayanannya.

2. Prinsip-prinsip yang berkenaan dengan permasalahan individu.

a. Bimbingan dan konseling berurusan dengan hal-hal yang menyangkut pengaruh kondisi mental/fisik individu terhadap penyesuaian dirinya di rumah, di sekolah serta dalam kaitannya dengan kontak sosial dan pekerjaan dan sebaliknya pengaruh lingkungan terhadap kondisi mental dan fisik individu.

b. Kesenjangan sosial, ekonomi dan kebudayaan merupakan faktor timbulnya masalah pada individu dan kesemuanya menjadi perhatian utama pelayanan bimbingan.

3. Prinsip-prinsip yang berkenaan dengan program layanan:

a. Bimbingan dan konseling merupakan bagian integral dan pendidikan dan pengembangan individu; oleh karena itu program bimbingan harus disesuaikan dan dipadukan dengan program pendidikan serta pengembangan peserta didik. 
b. Bimbingan dan konseling harus fleksibel, disesuaikan dengan kebutuhan individu, masyarakat dan kondisi lembaga.

c. Bimbingan dan konseling disusun secara berkelanjutan dan jenjang pendidikan yang terendah sampai yang tertinggi. Terhadap isi dan pelaksanaan program bimbingan dan konseling perlu adanya penilaian yang teratur dan terarah.

4. Prinsip-prinsip yang berkenaan dengan pelaksanaan pelayanan

a. Bimbingan dan konseling harus diarahkan untuk pengembangan individu yang akhirnya mampu membimbing diri sendiri dalam menghadapi permasalahannya.

b. Dalam proses bimbingan dan konseling keputusan yang diambil dan hendak dilakukan oleh individu hendaknya atas kemauan individu itu sendiri, bukan karena kemauan atas desakan dan pembimbing atau pihak lain.

c. Permasalahan individu harus ditangani oleh tenaga ahli dalam bidang yang relevan dengan permasalahan yang dihadapi. d. Kerjasama antara pembimbing, guru dan orang tua amat menentukan hasil pelayanan bimbingan.

e. Pengembangan program pelayanan bimbingan dan konseling ditempuh melalui pemanfaatan yang maksimal dan hasil pengukuran dan penilaian terhadap individu yang terlibat dalam proses pelayanan dan program bimbingan dan konseling itu sendiri.

Suharsimi Arikunto (2011: 61-64) menguraikan tujuh jenis kegiatan layanan bimbingan adalah sebagai berikut:

1. Layanan orientasi.

Kegiatan layanan orientasi diberikan kepada siswa kelas I pada hari-hari pertama masuk sekolah.

2. Layanan informasi.

Kegiatan layanan informasi diberikan kepada siswa yang membutuhkan. Layanan ini dapat dilaksanakan secara individual maupun kelompok. Materi layanan diperlukan oleh siswa kelas I, II, atau III yang mempunyai kebutuhan khusus.

3. Layanan bimbingan penempatan dan penyaluran. Kegiatan layanan ini baru dapat dilakukan apabila 
guru pembimbing sudah mengenal siswa dengan baik dan atau mempunyai catatan yang lengkap tentang kondisi dan keunikan siswa. Layanan penempatan juga dapat dilakukan pada akhir tahun pelajaran ketika terjadi penggeseran tempat siswa di kelas tertentu.

4. Layanan pembelajaran Kegiatan layanan pembelajaran dimaksudkan memberi bantuan kepada siswa berkenaan dengan permasalahan bantuan kepada siswa berkenaan dengan permasalahan akademik.

5. Layanan konseling perorangan. Kegiatan layanan konseling perorangan dilakukan terhadap siswa yang mengalami masalah pribadi, masalah sosial, masalah belajar, dan masalah karier.

6. Layanan bimbingan kelompok. Kegiatan layanan bimbingan kelompok dilakukan apabila ada permasalahan secara umum. Layanan bimbingan kelompok dapat dilakukan terhadap kelompok kecil atau kelompok besar misalnya kelas. Layanan kelompok ini sebaiknya dilakukan melalui dinamika kelompok.

7. Layanan konseling kelompok. Kegiatan layanan konseling kelompok dilakukan apabila ada persamaam masalah pribadi tetapi ada persamaan siswa lain. Layanan konseling kelompok dapat dilakukan ketika pembimbing membantu siswa yang mengalami masalah akademik.

c. Profesionalisasi Bimbingan dan Konseling

Perkembangan ilmu pengetahuan dan teknologi menuntut konsekuensi, persyaratan yang semakin berat dan kompleks terhadap petugas bimbingan dan konseling di madrasah. Pembimbing madrasah adalah pembimbing yang profesional, personal dan sosial, memiliki persyaratan dasar, keterampilan teknis serta didukung sikap kepribadian yang mantap.

Guru bimbingan dan konseling/ konselor yang profesional harus memiliki:

1. Kompetensi profesional, artinya ia memiliki pengetahuan yang luas dan mendalam tentang bimbingan dan konseling.

2. Kompetensi personal, artinya memiliki sikap kepribadian yang mantap, berarti ia memiliki sikap kepribadian yang patut diteladani sehingga ia mampu melaksanakan kepemimpinan yang dikemukakan oleh $\mathrm{Ki}$ Hajar Dewantara yaitu "Ing Ngarsa Sung Tulada, Ing Madya Mangun Karsa, dan Tut Wuri Handayani".

3. Kompetensi sosial, artinya ia 


menunjukkan kemampuan
berkomunikasi yang sebaik-
baiknya yang $\begin{array}{r}\text { berarti } \\ \text { mengutamakan nilai }\end{array}$
$\begin{aligned} & \text { kemanusiaan dari pada nilai } \\ & \text { kebendaan/material). }\end{aligned}$

Selain persyaratan yang dimiliki oleh konselor tersebut, konselor hendaklah juga memiliki sifat-sifat yang dapat dilihat dari kematangan emosinya, seperti tampak dalam pengaturan hidup pribadinya. Ia menunjukkan sifat sabar, bijaksana, tenang, memiliki perasaan humor, harga diri dan sosial serta kemampuan untuk menerima kritik-kritik dengan hati terbuka. Ia harus memiliki kesehatan yang baik, suara yang menyenangkan dan daya tarik. Ia harus mampu menempatkan diri dalam suatu sikap yang memungkinkan ia dapat melihat dan memahami keadaan-keadaan dan dorongan di rumah (keluarga) serta kehidupan masyarakat yang membuat anak melakukan halhal yang tidak diinginkan atau mengalami kegagalan dalam belajarnya atau yang lainnya.

Guru BK/Konselor harus berusaha memenuhi standar profesi sebagaimana yang termaktub dalam Peraturan Menteri Pendidikan Nasional Nomor 27 Tahun 2008 tentang Standar Kualifikasi Akademik dan Kompetensi Konselor bahwa kualifikasi akademik konselor dalam satuan pendidikan pada jalur pendidikan formal dan nonformal adalah:

1. Sarjana pendidikan (S-1) dalam bidang bimbingan dan konseling; dan

2. Berpendidikan profesi konselor.

Rumusan Standar Kompetensi Konselor telah dikembangkan dan dirumuskan atas dasar kerangka pikir yang menegaskan konteks tugas dan ekspektasi kinerja konselor. Namun, bila ditata ke dalam empat kompetensi pendidik sebagaimana tertuang dalam PP 19/2005, makarumusankompetensi akademik dan profesional konselor dapat dipetakan dan dirumuskan ke dalam kompetensi pedagogik, kepribadian, sosial, dan profesional sebagai berikut.

1. Kompetensi Pedagogik:

a. Menguasai teori dan praksis pendidikan kompetensi kepribadian;

b. Mengaplikasikan perkembangan fisiologis dan psikologis serta perilaku konseli; dan

c. Menguasai esensi pelayanan bimbingan dan konseling dalam jalur, jenis, dan jenjang satuan pendidikan.

2. Kompetensi kepribadian:

a. Beriman dan bertakwa kepada Tuhan Yang Maha Esa;

b. Menghargai dan menjunjung tinggi nilai-nilai kemanusiaan, 
individualitas dan kebebasan memilih;

c. Menunjukkan integritas dan stabilitas kepribadian yang kuat; dan

d. Menampilkan kinerja berkualitas tinggi.

3. Kompetensi sosial

a. Mengimplementasikan kolaborasi intern di tempat bekerja;

b. Berperan dalam organisasi dan kegiatan profesi bimbingan dan konseling; dan

c. Mengimplementasikan kolaborasi antarprofesi.

4. Kompetensi profesional:

a. Menguasai konsep dan praksis asesmen untuk memahami kondisi, kebutuhan, dan masalah konseli;

b. Menguasai kerangka teoretik dan praksis bimbingan dan konseling;

c. Merancang program bimbingan dan konseling;

d. Mengimplementasikan program bimbingan dan konseling yang komprehensif;

e. Menilai proses dan hasil kegiatan bimbingan dan konseling;

f. Memiliki kesadaran dan komitmen terhadap etika professional; dan

g. Menguasai konsep dan praksis penelitian dalam bimbingan dan konseling.
Guru BK atau konselor harus memiliki profesionalisme di dalam menjalankan profesinya. Profesionalisme menunjuk kepada komitmen guru BK atau konselor sebagai anggota profesi untuk meningkatkan strategi-strategi yang digunakannya dalam melakukan pekerjaan yang sesuai dengan profesinya. Wujud dari profesionalisme guru BK atau konselor yaitu melakukan profesionalisasi diri untuk dapat melaksanakan kinerja yang bermutu sesuai dengan sifat, tugas dan kegiatannya (P4TK Pendidikan Jasmani dan Bimbingan Konseling, 2013:119).

\section{A. Implemenentasi Program Bimbingan dan Konseling dalam Kurikulum 2013 dan Profesionalisasi Bimbingan dan Konseling}

Implementasi kurikulum 2013 akan dapat menimbulkan masalah bagi peserta didik di madrasah, baik di madrasah tsanawiyah maupun aliyah, manakala tidak mampu menentukan pilihan arah peminatan kelompok mata pelajaran dan mata pelajaran secara tepat, sehinga akan menimbulkan kesulitan dalam belajar dan kecenderungan gagal dalam belajar.

Penentuan arah peminatan kelompok mata pelajaran dan mata pelajaran hendaknya sesuai dengan kemampuan dasar umum (kecerdasan), bakat, dan minat 
serta kecenderungan pemilihan sekolah/madrasah bagi peserta didik tsanawiyah dan pemilihan jurusan pada fakultas atau karier yang akan dipilihnya.

Pelayanan

bimbingan

konseling (BK) utamanya pelayanan peminatan diperlukan guru bimbingan dan konseling yang mumpuni. Pelayanan BK peminatan peserta didik telah diamanatkan dalam kurikulum 2013 bagian integral dari pelayanan BK secara keseluruhan pada setiap satuan pendidikan. Kegiatan bimbingan yang lebih luas diisi dengan layanan terhadap arah peminatan yang menjadikan kemandirian peserta didik sesuai dengan potensi, bakat, dan minat meraka masing-masing. Untuk itu, guru BK/konselor untuk setiap tahunan menyusun program bimbingan dan konseling.

Program bimbingan dan konseling diartikan seperangkat kegiatan bimbingan dan konseling yang dirancang secara terencana, terorganisasi, terkoordinasi selama periode waktu tertentu dan dilakukan secara kait mengait untuk mencapai tujuan (Kemendikbud, 2013:14).

Sebelum melaksanakan layanan bimbingan dan konseling, guru BK/konselor terlebih dahulu membuat program kerja yaitu program bimbingan dan konseling, program BK yang disusun memuat perencanaan, pelaksanaan, dan penilaian.
Implementasi BK dalam Kurikulum 2013 mengamanatkan layanan peminatan peserta didik. Bukan berarti bahwa layanan BK hanya memuat layanan peminatan tetapi layayanan peminatan merupakan bagian dari pelayanan BK secara utuh.

Implementasi prinsip-prinsip bimbingan dan konseling di madrasah belum sepenuhnya dilaksanakan karena adanya beberapa faktor yang kurang menunjang, antara lain:

a. Tidak adanya tenaga yang profesional, petugas BK yang ada belum banyak mengetahui seluk-beluk bimbingan dan konseling;

b. Dukungan dari pihak sekolah yang perlu ditingkatkan;

c. Partisipasi kepala sekolah, guru dan staf sekolah lainnya;

d. Sarana dan prasarana yang belum memadai; dan

e. Program bimbingan dan konseling yang belum berjalan sebagaimana mestinya.

Untuk dapat melaksanakan prinsip-prinsip itu, konselor di madrasah perlu mengetahui dan memahami hakikat bimbingan dan konseling. Memahami hakikat bimbingan dan konseling tidak dapat dipisahkan dan pandangan dasar bimbingan dan konseling tentang manusia. 
Konselor memandang klien itu baik, artinya ia harus yakin bahwa klien mengandung kebaikankebaikan pada dirinya yang perlu dikembangkan. Tugas konselor ialah membantu klien dalam menemukan, mengungkapkan dan mengembangkan kebaikankebaikan pada din klien itu.

Manusia memiliki kecenderungan-kecenderungan yang positif, seperti awal kejadiannya, yang dalam ajaran agama Islam disebut "fitrah", fitrah berarti bersih, suci, kecenderungan untuk melakukan yang positif dan memiliki jiwa untuk menerima kebenaran. Kebenaran yang dimiliki manusia adalah kebenaran untuk menerima agama, yang merupakan fitrah yang dibentuk oleh Tuhan sejak masa berada didalam kandungan. Pandangan ini bersumber dari Alquran surat Ar-Rūm: 30 seperti berikut:
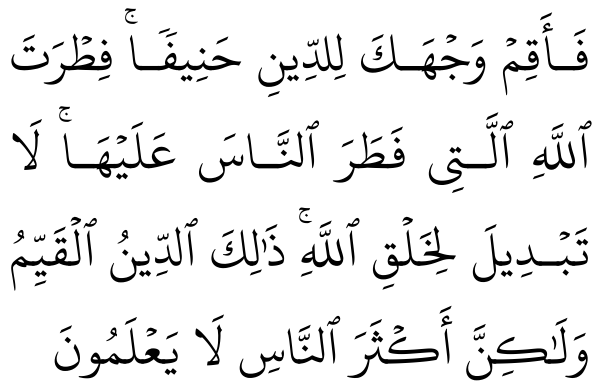

"Maka hadapkanlah wajahmu dengan lurus kepada agama (Allah); (Tetaplah atas) fitrah Allah yang telah menciptakan manusia menurut fitrah Allah. (Itulah) agama yang lurus; tetapi kebanyakan manusia tidak mengetahui." (Q.S. 30:30).
Muhammad Rasulullah Saw. pernah bersabda bahwa setiap manusia yang dilahirkan di dunia terbentuk dalam dirinya suatu kemampuan dasar yang positif yang disebut "Fitrah", kemudian untuk perkembangan selanjutnya tergantung pada lingkungan dimana ia berada, terutama lingkungan keluarga, yaitu orang tua.

Setiap anak dilahirkan dalam keadaan fitrah, sampai ia fasih mengatakan sesuatu, maka orang tuanyalah (ibu dan bapaknya) yang menjadikan anak tersebut Yahudi, Nasrani atau Majusi.

$\mathrm{K}$ e c e $\mathrm{nde} r \mathrm{ung}$ a $\mathrm{n}$ kecenderungan yang positif pada manusia dipertahankan dan dipelihara, tetapi kadangkadang dalam perkembangannya mengalami hambatan yang akan menimbulkan masalah bagi dirinya. Dalam hal ini, konselor bertugas memberikan bimbingan dan pengarahan kepada klien sehingga masalah yang menjadi hambatan bagi klien itu dapat teratasi.

Pedoman

petunjuk pelaksanaan bimbingan dan konseling disebutkan fungsi bimbingan dan konseling sebagai berikut:

1. Fungsi yaitu fungsi bimbingan dan konseling yang akan menghasilkan pemahaman tentang sesuatu oleh pihak pihak tertentu sesuai dengan 
keperluan pemahaman siswa; pemahaman yang meliputi:

a. Pemahaman tentang diri siswa, terutama oleh siswa itu scndiri, orang tua, guru dan pembimbing.

b. Pemahaman lingkungan

tentang siswa (terutama didalamnya lingkungan keluarga dan sekolah), terutama oleh siswa itu sendiri, orang tua, guru dan pembimbing.

c. Pemahaman tentang lingkungan yang lebih luas (termasuk didalamnya informasi pendidikan, budaya atau nilai-nilai) terutama oleh siswa.

2. Fungsi pencegahan, yaitu fungsibimbingandankonseling yang akan menghasilkan tercegahnya yang akan mengganggu, menghambat ataupun menimbulkan kesulitan-kesulitan dalam proses perkembangannya.

3. Fungsi perbaikan, yaitu fungsi bimbingan dan konseling yang akan menghasilkan terpecahnya atau teratasinya berbagai permasalahan yang dialami oleh siswa.

4. Fungsi pemeliharaan dan pengembangan, yaitu fungsi bimbingan dan konseling yang akan terpelihara dan berkembangnya berbagai potensi dan kondisi siswa dalam rangka perkembangan dirinya secara mantap dan berkelanjutan.

Fungsi-fungsi tersebut di atas dapat diwujudkan di madrasah melalui penyelenggaraan berbagai layanan dan kegiatan pendukung bimbingan dan konseling untuk mencapai hasil sebagaimana terkandung di dalam masingmasing fungsi itu.

Individu akan menghadapi berbagai tantangan dalam kehidupan yang berbeda satu sama lain. Oleh karena itu individu akan memperoleh bidang bimbingan yang berbeda pula, sesuai dengan kebutuhan perkembangan individu dan tantangan yang dituntut oleh masyarakat lingkungannya dalam mewujudkan dirinya.

Oleh karena itu bimbingan dan konseling hendaknya memungkinkan peserta didik mengenal dan menerima lingkungannya secara positif dan dinamis, serta mengambil ke putusan-keputusan, mengarahkan dan mewujudkan diri sendiri secara efektif dan produktif sesuai dengan peranan yang diinginkannya di masa depan.

Kegiatan bimbingan dan konseling secara keseluruhan mencakup empat bidang, yaitu bimbingan pribadi, bimbingan sosial, bimbingan belajar, dan bimbingan karier.

Implementasi bidang-bidang tersebut di Madrasah adalah 
sebagai berikut:

1. Bidang Bimbingan Pribadi.

Pada bidang ini pelayanan bimbingan dan konseling dapat berupa bantuan kepada siswa dalam menemukan dan mengembangkan pribadi yang beriman dan bertakwa terhadap Allah Swt., mantap dan mandiri, serta sehat jasmani dan rohani.

2. Bidang Bimbingan Sosial.

Pelayanan bimbingan dan konseling di madrasah juga dapat membantu siswa mengenal dan berhubungan dengan lingkungan sosial yang dilandasi ajaran agama Islam, akhlakul karimah, tanggung jawab terhadap masyarakat dan bangsa.

3. Bidang Bimbingan Belajar.

Madrasah bertujuan membantu siswa untuk menumbuhkan dan mengembangkan diri sebagai muslim yang baik karakter, memiliki sikap dan kebiasaan belajar yang baik, menguasai ilmu pengetahuan dan keterampilan, mempersiapkan siswa untuk melanjutkan ke perguruan tinggi, serta memiliki kepekaan terhadap perkembangan IPTEK. Untuk memberikan bimbingan belajar kepada siswa Madrasah secara baik, dapat dilakukannya sebagai berikut: a. Mencarikan cara-cara belajar efisien dan efektif bagi seorang anak atau sekelompok anak.

b. Menunjukkan cara-cara mempelajari sesuatu dan menggunakan buku pelajaran.

c. Memberikan informasi bagaimana memanfaatkan perpustakaan.

d. Mengerjakantugas sekolah dan mempersiapkan diri dalam ulangan dan ujian.

e. Memilih suatu bidang studi (mayor atau minor) sesuai dengan bakat, minat, kecerdasan, citacita dan kondisi fisik atau kesehatannya.

f. Menunjukkan cara-cara menghadapi kesulitan dalam bidang studi tertentu.

g. Menentukan pembagian waktu dan perencanaan jadwal belajarnya.

h. Memilih pelajaran tambahan baik yang berhubungan dengan pelajaran di sekolah maupun untuk mengembangkan bakat dan kariernya dimasa depan.

Layanan bimbingan dan belajar yang tersebut di atas, dapat diberikan siswa madrasah 
untuk meningkatkan prestasi siswa dan kualitas sekolah, sehingga eksistensi ilmu pengetahuan yang dimiliki oleh mereka tidak berbeda dengan siswa sekolah umum.

4. Bidang Bimbingan Karier.

Pada bidang bimbingan karier, pelayanan bimbingan dan konseling di madrasah ditunjukkan untuk mengenali potensi diri, mengembangkan dan memantapkan pilihan karier, serta mengembangkan keterampilan sebagai muatan lokal yang menunjang kemandirian dan kreatif yang dicanangkan sejak kurikulum madrasah tahun 1984, bahwa bimbingan karier diberikan kepada siswa agar mereka memiliki wawasan lebih awal dan luas mengenai pendidikan lanjutan dan dunia kerja dalam batas tertentu. Bimbingan karier diperlukan di madrasah antara lain dikarenakan beberapa faktor, seperti perkembangan sosial budaya, peranan sekolah dan tanggungjawab pada umumnya, cita-cita siswa terhadap pekerjaan, harapan orang tua dan sebagainya.

Layanan peminatan menjadi hal yang mendapat perhatian khusus dalam kurikulum 2013. Layanan peminatan yang dilaksanakan oleh guru BK/konselor adalah untuk memfasilitasi peserta didik dalam memilih dan menetapkan kelompok peminatannya berdasarkan data prestasi akademik dan non akademik serta dukungan orang tua.

Pelayanan peminatan peserta didik menuntut guru BK/konselor dalam melaksanakan tugasnya secara professional. Guru BK/ konselor harus berusaha memenuhi standar profesi sebagaimana yang termaktub dalam Peraturan Menteri Pendidikan Nasional Nomor 27 Tahun 2008 tentang Standar Kualifikasi Akademik dan Kompetensi Konselor bahwa kualifikasi akademik konselor dalam satuan pendidikan pada jalur pendidikan formal dan nonformal adalah:

1. Sarjana pendidikan (S-1) dalam bidang Bimbingan dan Konseling. Guru BK/Konselor di madrasah masih banyak yang berpendidikan bukan dari S-1 Bimbingan dan Konseling, dari beberapa madrasah memberikan informasi bahwa guru BK-nya bukan dari S-1 Program BK atau Psikologi. Dalam hal ini, Kementerian Agama dalam bidang ini adalah Direktorat Guru dan Tenaga Kependidikan Madrasah sudah selayaknya untuk melakukan pendidikan dan pelatihan bimbingan dan konseling bagi guru BK, atau short course BK, atau dikuliahkan pada Program BK. 
2. Berpendidikan profesi konselor.

Rumusan Standar Kompetensi Konselor telah dikembangkan dan dirumuskan atas dasar kerangka pikir yang menegaskan konteks tugas dan ekspektasi kinerja konselor yang dirumuskan ke dalam kompetensi pedagogik, kepribadian, sosial, dan profesional.

Persyaratan lebih khusus yang harus dimiliki oleh pembimbing yang bertugas di madrasah antara lain:

1. Meyakini akan kebenaran agamanya, menghayati dan mengamalkannya.

2. Mempunyai keyakinan bahwa setiap siswa dasarnya baik dan dapat dibimbing kearah perkembangan yang optimal.

3. Memiliki cinta yang mendalam, ketulusan, pengertian, lemah lembut, dan bijaksana terhadap siswa yang dibimbingnya.

Namundemikian,implementasi dalam layanan bimbingan masih dapat dilaksanakan walaupun dengan keterbatasan dan kemampuan yang dimiliki guru BK di madrasah, mereka dalam proses memberikan bimbingan dan konseling seorang konselor memerlukan teknik komunikasi yang tepat, menyenangkan dan dapat membangkitkan kesadaran siswa untuk berubah kearah yang lebih baik, dengan salah satu cara menunjukkan sifat positif yang ada pada diri siswa itu, berilah pandangan yang menyebabkan mereka senang dan penuh percaya diri, seperti sabda Nabi Saw.: "Permudahkanlah dalam urusan mereka dan janganlah mempersulit, gembirakanlah mereka dan janganlah melakukan tindakan yang menyebabkan mereka lari dari dirimu." (Hadis)

\section{A. Kesimpulan}

Implemenentasi program bimbingan dan konseling dalam kurikulum 2013 dan profesionalisasi bimbingan dan konseling masih dapat dilaksanakan di madrasah, meskipun program BK yang telah dibuat masih terbartas pada pemenuhan administrasi. Tidak sedikit Guru BK yang telah bertugas sesuai dengan ijazah pendidikan formalnya atau Sertifikasi Pendidik sebagai guru BK, namun beberapa hal perlu ditingkatkan misalnya meningkatkan untuk guru BK yang bukan dari jurusan BK. Pelaksanaan bimbingan dan konseling yang selama ini telah dilakukan oleh pembimbing dengan baikwalaupun di antara mereka tidak banyak yang telah memiliki kualifikasi tertentu, sehingga ia memberikan bimbingan secara alamiah dan berdasarkan pengalaman.

\section{B. Rekomendasi}

Agar pelaksanaan bimbingan dan konseling di madrasah dapat berjalan sebagaimana mestinya, maka pembimbing/konselor 
berupaya untuk meningkatkan pemahaman bimbingan dan konseling melalui upaya pelatihan, workshop, dan membaca referensi BK baik berupa buku atau regulasi.
Kepala madrasah harus proaktif untuk melakukan pembinaan terhadap guru BK/konselor dalam rangka peningkatan kompetensinya.

\section{DAFTAR PUSTAKA}

Arikunto, Suharsimi, 2011, Penilaian \& Penelitian Biang Bimbingan dan Konseling, Yogyakarta: Aditya Media.

Aqib, Zaenal, 2012, Ikhtisar Bimbingan dan Konseling, Bandung: Yrama Widya.

Departemen Pendidikan dan Kebudayaan, 2004, Kurikulum Sekolah Menengah Umum (SMU). Petunjuk Pelaksanaan Bimbingan dan Konseling, Jakarta.

http://whiteacademic.blogspot.com/2015/03/pengertian-dan-jenis-jenispenelitian. html diunduh tanggal 4 November 2018.

Kementerian Pendidikan dan Kebudayaan, 2013, Modul Diklat Peningkatan Kompetensi Guru BK/Konselor: Kurikulum 2013 dan Profesionalisasi Bimbingan dan Konseling, Jakarta: P4TK Pendidikan Jasmani dan Bimbingan Konseling.

Kementerian Pendidikan dan Kebudayaan, 2013, Modul Diklat Peningkatan Kompetensi Guru BK/Konselor: Implementasi Program Bimbingan dan Konseling Dalam Kurikulum 2013, Jakarta: P4TK Pendidikan Jasmani dan Bimbingan Konseling.

Prayitno dan Erman Amti, 2015, Dasar-dasar Bimbingan dan Konseling, Jakarta: Rineka Cipta.

Sabarti Bahreisy, 1987, Riadus Shalihin, Bandung: PT. Al-Ma'arif.

Tohirin, 2009, Bimbingan dan Konseling di Sekolah dan Madrasah (Berbasis Integrasi), Jakarta: Raja Grafindo Persada. 